\title{
Physicochemical Quality of Water and Influence on the Dynamics of Bacteria Circulating in Water Points for Domestic Use in Yaoundé (Cameroon)
}

\author{
Ngong Ankiambom Innocent ${ }^{1,2,3}$, Ajeagah Gideon Aghaindum ${ }^{1}$, Kapso Tchouankep Mireille ${ }^{1,2, ~ *, ~}$ \\ Nguepidjio Gilbert ${ }^{2,5}$, Sotchang Mbounga Ines Olivia ${ }^{2}$, Fouossong Banhatio Ignace ${ }^{2}$, \\ Nnah Mbele Jean Pierre ${ }^{6}$, Kechia née Kom Assumpta Ikei ${ }^{4}$, Enoka Patrice ${ }^{2}$ \\ ${ }^{1}$ Laboratory of Hydrobiology and Environment, Department of Animal Biology and Physiology, Faculty of Sciences, University of Yaounde \\ 1, Yaounde, Cameroon \\ ${ }^{2}$ Public School of Medical Laboratory Sciences Yaounde, Ministry of Public Health, Yaounde, Cameroon \\ ${ }^{3}$ Higher Institute of Health Professions Cameroon (ISPS), Higher University Institutions of Health, Ministry of Public Health, Yaounde, \\ Cameroon \\ ${ }^{4}$ Labolatory of Application, Public School of Medical Laboratory Sciences Yaounde, Ministry of Public Health, Yaounde, Cameroon \\ ${ }^{5}$ Department of Infectious Diseases, Faculty of Health Sciences, Distant Production House University (DPHU), Brazzaville, Gabon \\ ${ }^{6}$ Laboratory of Parasitology, Efoulan District Hospital, Ministry of Public Health, Yaounde, Cameroon
}

\section{Email address:}

mireillekapso@yahoo.fr (K. T. Mireille)

${ }^{*}$ Corresponding author

\section{To cite this article:}

Ngong Ankiambom Innocent, Ajeagah Gideon Aghaindum, Kapso Tchouankep Mireille, Nguepidjio Gilbert, Sotchang Mbounga Ines Olivia, Fouossong Banhatio Ignace, Nnah Mbele Jean Pierre, Kechia née Kom Assumpta Ikei, Enoka Patrice. Physicochemical Quality of Water and Influence on the Dynamics of Bacteria Circulating in Water Points for Domestic Use in Yaoundé (Cameroon). International Journal of Natural Resource Ecology and Management. Vol. 4, No. 5, 2019, pp. 112-119. doi: 10.11648/j.ijnrem.20190405.12

Received: July 6, 2019; Accepted: July 30, 2019; Published: August 20, 2019

\begin{abstract}
A study seek to identify the bacterial germs that colonize aquatic environments in relation to some abiotic parameters of the environment was conducted from March to September 2018 in five neighborhoods of Yaounde on 14 wells, 7 sources and 5 streams. The sampling stations were chosen according to the sources of pollution, their geographical distribution, and their importance for the user populations. Samples and physico-chemical and bacteriological analyzes were carried out using appropriate techniques. The physicochemical analyzes revealed that the samples are generally well oxygenated (Dissolved oxygen $(8 \mathrm{mg} / \mathrm{L})$ ), rich in organic and mineral matter $\left(\mathrm{BOD}_{5}=41,66 \pm 20,5 \mathrm{mg} / \mathrm{L}\right.$ of oxygen) and loaded in particles (Total dissolved solids $=121,04 \pm 94,4 \mathrm{mg} / \mathrm{L}$, Suspended Solids $=30,67 \pm 22,0 \mathrm{mg} / \mathrm{L}$ ). The results of the bacteriological analyzes show that these waters host many bacterial communities such as total coliforms and fecal coliforms with a frequency of occurrence at more than $40 \%$ of species such as Escherichia coli, Serratia marcescens, Klebsiella oxytoca, Klebsiella pneumoniae, Providencia rettgeri, Alcaligenes denitrificans, Providencia stuartii, Enterobacter gergoviae, Enterobacter cloacae, Pseudomonas aeruginosa. Pseudomonas fluorescens and Citrobacter koseri, all gram-negative bacteria. The densities of these pathogens are significantly related to suspended solids, $\mathrm{BOD}_{5}$, nitrite and orthophosphate levels, and the availability of dissolved oxygen $(\mathrm{P}<0.05)$. The origin of faecal pollution in the water points studied varies according to the sites and would be either human, animal or mixed. The dynamics of the abundances of the different germs identified and their occurrence in the environment would be related to the physicochemical quality of the water.
\end{abstract}

Keywords: Physico-chemistry, Water, Pollution, Bacteria, Environment 


\section{Introduction}

In Cameroon, precisely in Yaounde, the political capital, the insufficiency in the supply of drinking water of public distribution forces many people to resort to the water of springs, wells and streams to satisfy their needs. This resource is not always free of pollutants and its poor quality can be induced by anthropogenic activities, including pollution, as well as poor sanitation and hygiene $[1,2]$. The multiplication of pathogenic microorganisms, their virulence and their resistance during the potabilization could be favored by abiotic variables. Good monitoring of water quality requires the control of microbiological quality and environmental factors that can influence or regulate life. It is in this sense that the present work aimed to identify the bacteria circulating in the well water, springs and streams of the city of Yaoundé in relation to the physicochemical quality of these water bodies. More specifically, it was a question of measuring the physicochemical parameters in some water bodies, to identify the bacteria circulating in these waters, and finally to evaluate the influence of the abiotic variables on the germs present in these waters.

\section{Material and Methods}

\subsection{Study Site}

The study took place in five districts of the city of Yaoundé, capital of Cameroon and chief town of the central region. It is located $300 \mathrm{~km}$ from the Atlantic coast, between $3^{\circ} 5^{\prime}$ north latitude and $11^{\circ} 31^{\prime}$ east longitude. It is surrounded by 7 hills that would be responsible for the particular climate and the highest ones are located on the west and northwest side. Yaoundé has an area of 1361 ha in 2002 and a population of 2 million inhabitants in 2006 [3]. These districts are characterized by the lack of drinking water distribution network, the interest of the populations for the different water points and the sources of pollution of these water bodies. The city is located largely in the basin of the Mfoundi stream slope. The hydrographic network of the city is very dense and essentially composed of the Mfoundi stream and its tributaries. These provide natural drainage of runoff water and surface water that is discharged into the Mefou River, which in turn discharges its waters into the Nyong River where the current catchment area of the waters for the production of water is located. Drinking water for the city Yaoundé and its surroundings. Our study included wells, unmanaged wells, running waters and springs. These water points are distributed in six districts (Mvog-Ada, Essos, Melen, Mbankomo, Efoulan).

\subsection{Sampling, Physico-chemical and Bacteriological Analyzes}

The water samples were collected using 250, 500 and 1000 $\mathrm{ml}$ polyethylene bottles for physicochemical analyzes and $250 \mathrm{ml}$ sterile glass vials for the detection of bacteria [4]. The physicochemical analyzes were carried out at the Laboratory of Hydrobiology and Environment of the University of Yaounde 1 by volumetry, colorimetry with spectrophotometer HACH DR 3900 and with the aid of a portable multimeter HANNA model HI 9829. The bacteriological analyzes as to they were made at the laboratory of Efoulan District Hospital in Yaoundé. The bacteriological analysis consisted in determining the different colonizing pathogens of the water points. The search for the germs was done by seeding on solid medium and identification by biochemical techniques of the Api20e gallery. Indeed, this gallery comprises 20 microtubules containing dehydrated substrates. These microtubules are inoculated with a bacterial suspension that reconstitutes the tests. The reactions produced during the incubation period result in spontaneous color changes or revealed by the addition of reagents. The reading of the reactions is done using the reading table and the identification is obtained using an analytical catalog [5]. The results obtained were analyzed using SPSS software version 20.0 and XLSTAT. 2013.

\section{Results and Interpretation}

\subsection{Abiotic Parameters}

The dissolved gas contents of $\mathrm{CO}_{2}$ and $\mathrm{O}_{2}$ were relatively high overall. $\mathrm{CO}_{2}$ ranged from 4.4 (at W5) to 21.5 (at W6 and $\mathrm{W} 10$ ). The variation profile of the $\mathrm{CO}_{2}$ content is similar to that of dissolved oxygen. The waters were well oxygenated with an average of $57.3 \%$ except the critical values recorded at W5 and S4 (Figure 1). This satisfactory oxygenation could result from the mixing of the water during the drawing activities which are very regular in these water points. These parameters are favorable to the decomposition of the organic matter present and the proliferation of microorganisms in the water. Indeed, mineral compounds found in natural waters originate in the exchanges that occur between water and soil and between water and the atmosphere for gases $\left(\mathrm{CO}_{2}\right.$ and dissolved oxygen). Certain elements condition for a large part the development of biomass, which may modify the physicochemical characteristics of water [4].

Suspended materials ranged from 0 to $85 \mathrm{mg} / \mathrm{l}$ respectively in wells W11 and W2. The highest values were found in wells compared to sources and streams. TDS are abundant in sampled water points with maximum values of $450+94.48$ $\mathrm{mg} / \mathrm{l}$. translating a high load of soluble matter. The ORP showed high values overall with an average around $102+$ $28.89 \mathrm{mV}$. The $\mathrm{pH}$ varied between 4 and $7 \mathrm{uc}$ in these waters while the alkaline ion content reached a threshold of 240 $\mathrm{mg} / \mathrm{l}$ of $\mathrm{HCO}_{3}$ ions in the $\mathrm{W} 1$ well at Essos. In fact, the carbon species, the water dissociation products and the $\mathrm{pH}$ stability depend on the total concentration of $\mathrm{CO}_{2}$ and $\mathrm{HCO}_{3}-$ ions.

The biochemical oxygen demand $\left(\mathrm{BOD}_{5}\right)$ ranged from 15 $\mathrm{mg} / \mathrm{L}$ (at $\mathrm{W} 5$ and $\mathrm{W} 9$ ) to $105 \mathrm{mg} / \mathrm{L}$ at $\mathrm{W} 6$, reflecting a significant presence of organic matter. $\mathrm{BOD}_{5}$ represents the amount of oxygen used by bacteria, to partially decompose or to completely oxidize oxidizable biochemicals present in the 
water. It corresponds to the amount of oxygen (expressed in $\mathrm{mg} / \mathrm{l}$ ) required for decomposing microorganisms to degrade and mineralize in 5 days the organic matter present in a liter of polluted water. The higher the $\mathrm{BOD}_{5}$, the higher the amount of organic matter in the sample.
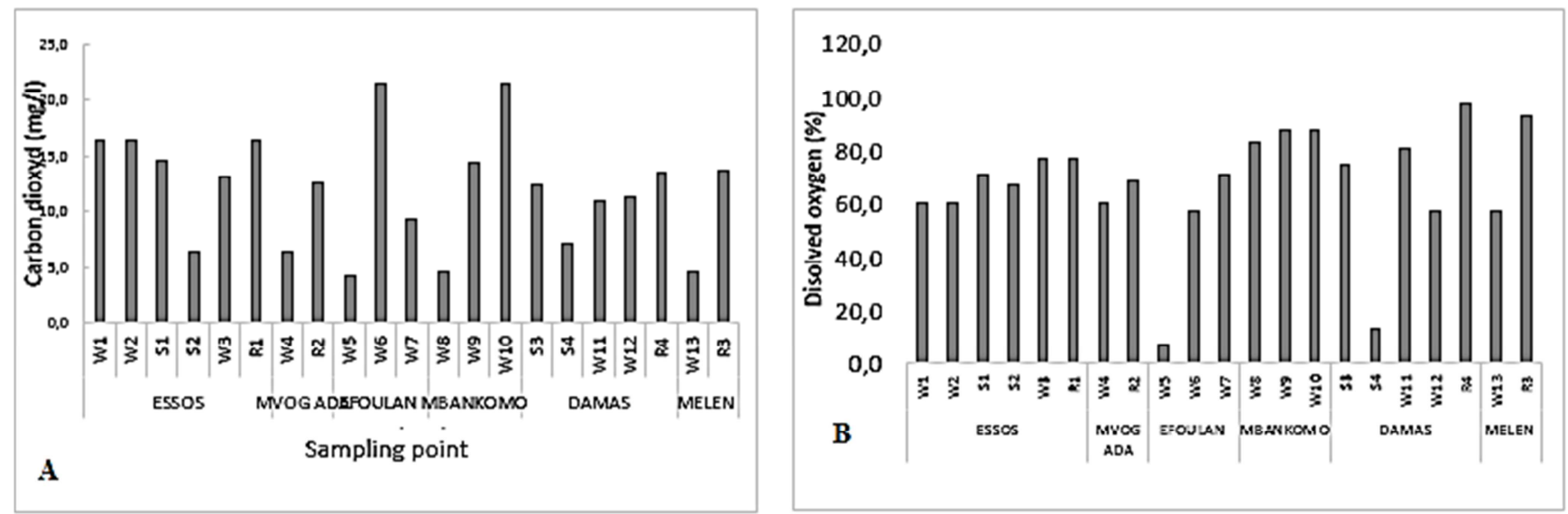

Figure 1. Spatial Variations in Dissolved Gas Content (A) Dissolved $\mathrm{CO}_{2},(B) \mathrm{O}_{2}$ Dissolved.
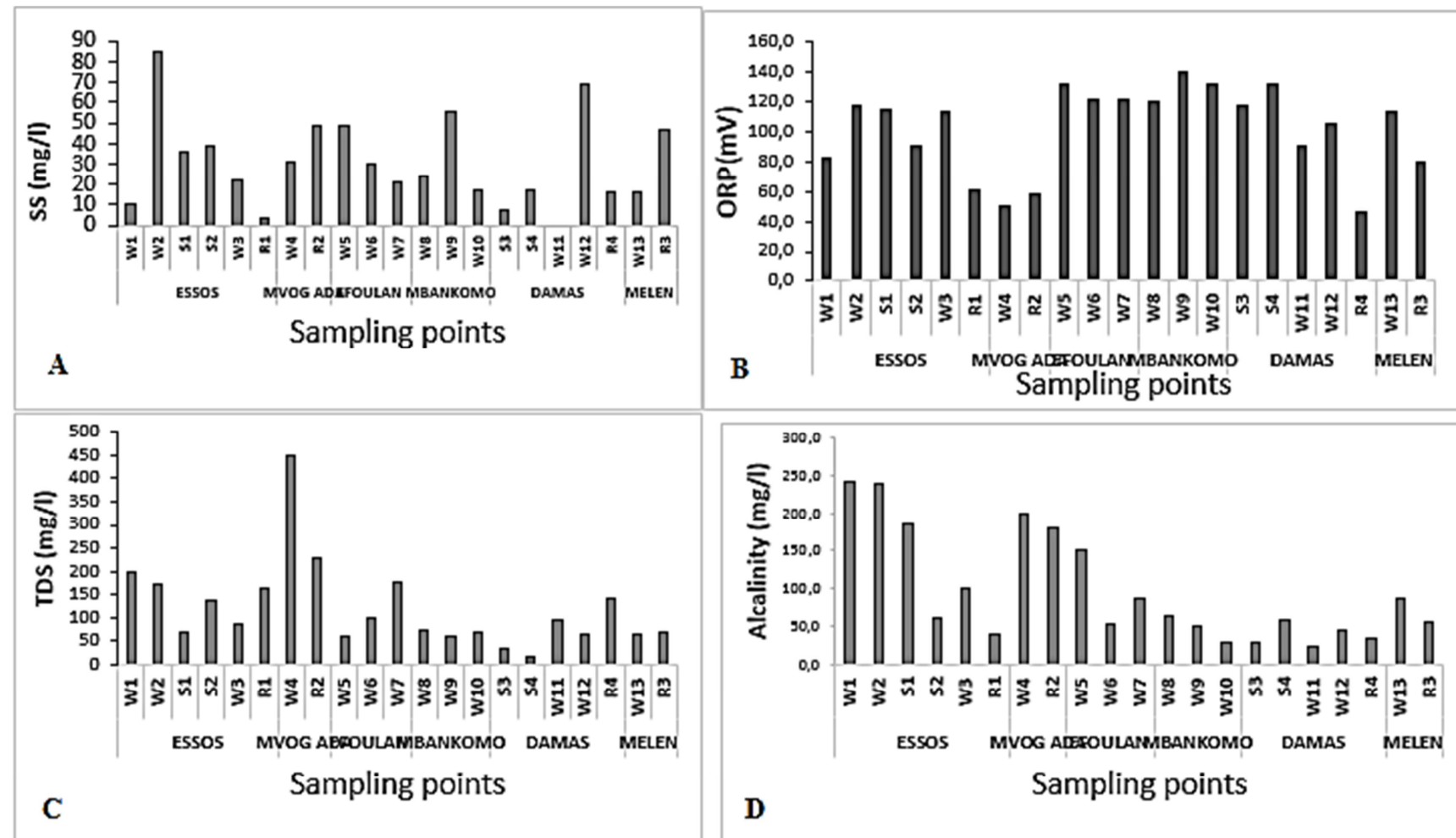

Figure 2. Spatial Variations of Suspended Solids (SS) (A), Oxydo-Reduction Potential (ORP) (B), Alkalinity (C) and Total Disolved Solids (TDS).

Nitrites for their part varied significantly from $0.1 \mathrm{mg} / \mathrm{L}$ (at $\mathrm{R} 4$ and $\mathrm{W} 7$ ) to $5.1 \mathrm{mg} / \mathrm{L}$ at S3 and W8. Nitrites are the salts of nitrous acid. They are toxic and their content in water is regulated at a maximum allowable concentration of $1 \mathrm{mg} / \mathrm{L}$. Nitrites can turn into nitrates and prevent microorganisms from fixing dissolved oxygen. The orthophosphate content ranged from 0.5 (at $\mathrm{R} 2$ and $\mathrm{S} 3$ ) to $3 \mathrm{mg} / \mathrm{L}$ (at $\mathrm{S} 4, \mathrm{R} 3$ ). Phosphates can be of natural origin (product of decomposition of living matter, leaching of minerals) but, at present, their presence in waters are rather of artificial origin (fertilizers, polyphosphates of detergent formulations, treated waters phosphates, chemical industry...). The total phosphorus content mainly comprises orthophosphates. Eutrophication can occur at relatively low phosphate concentrations $(0.05 \mathrm{mg} / \mathrm{L})$. A content of $2 \mathrm{mg} / \mathrm{L}$ of $\mathrm{PO}_{4^{-}}$in water, the class as being of poor quality.

\subsection{Biological Parameters}

As far as biological parameters are concerned, 31 germs have been isolated. The distribution in the different water points was thus: 18 germs were isolated in the wells among which those which predominate are Serratia marcescens (4 
germs) followed by Klebsiella oxytoca (3 germs). Then come Citrobacter koseri and Escherichia coli represented by 2 germs each and finally least represented by 1 germs: Enterobacter gergovia, Klebsiella pneumonia, Providencia rettgeri, Pseudomonas aeruginosa and Pseudomonas fluorescens. In spring waters, 4 sprouts have been isolated and distributed in equal quantities: Alcaligenes denitrificans, Enterobacter gergovia, Escherichia coli, Providencia rettgeri. In rivers, 9 sprouts have been identified, of which the most represented are Enterobacter cloacae and Escherichia coli 2 each; the others are in equivalent quantity
(1 germs).

The bacteria circulating in the analyzed waters are among others the Escherichia coli, Serratia marcescens, Klebsiella oxytoca, Klebsiella pneumoniae, Providencia rettgeri, Alcaligenes denitrificans, Providencia stuartii, Enterobacter gergoviae, Enterobacter cloacae, Pseudomonas aeruginosa species. Pseudomonas fluorescens and Citrobacter koseri with a frequency ranging from $3.2 \%$ for the Klebsiella pneumoniae species to $16.1 \%$ for the Escherichia coli species followed by Klebsiella Oxytoca and Pseudomonas fluorescens, $12.9 \%$.
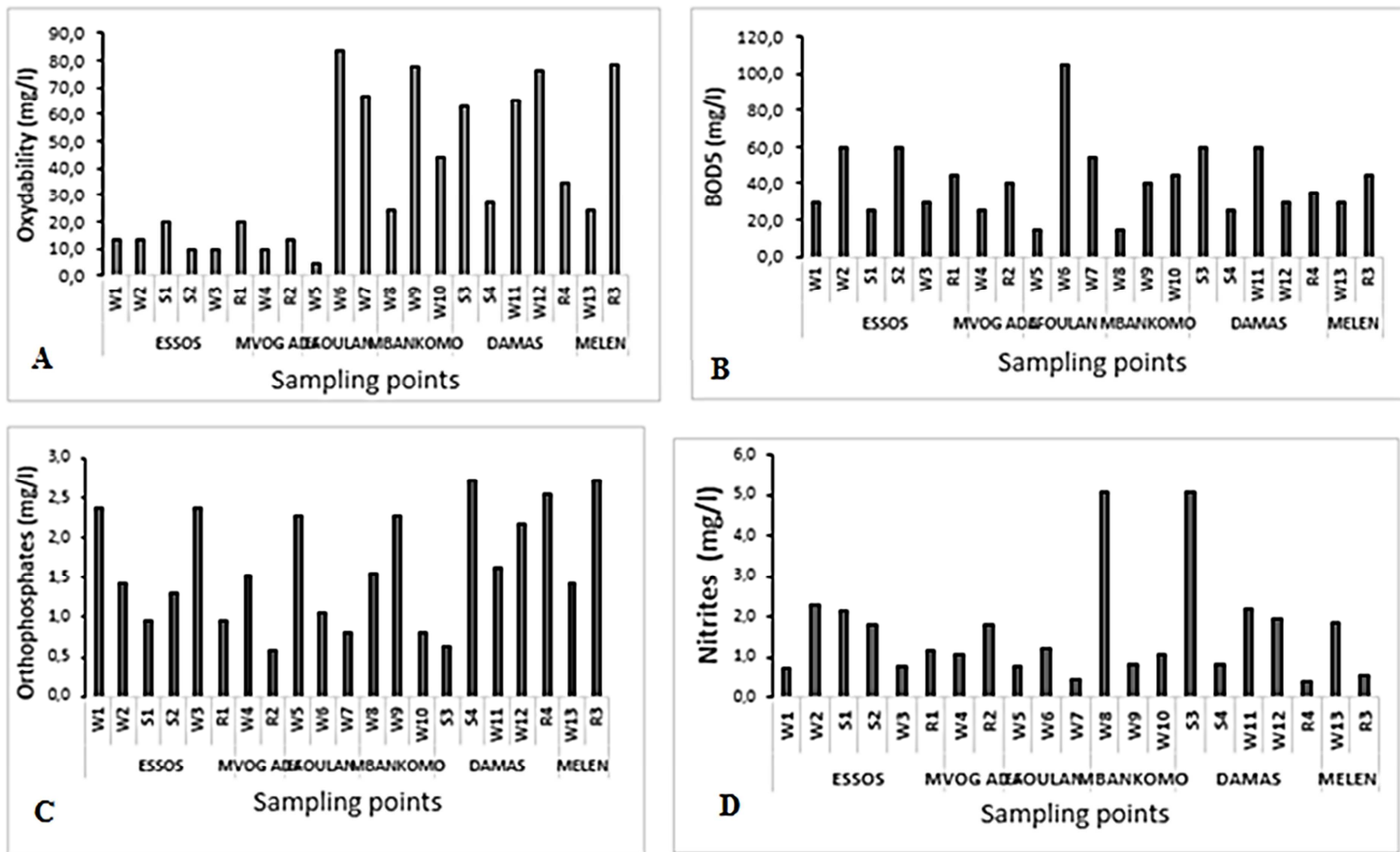

Figure 3. Spatial variations of Oxydability $(A), B O D_{5}(B)$, Orthophosphate $(C)$ and Nitrite (D).

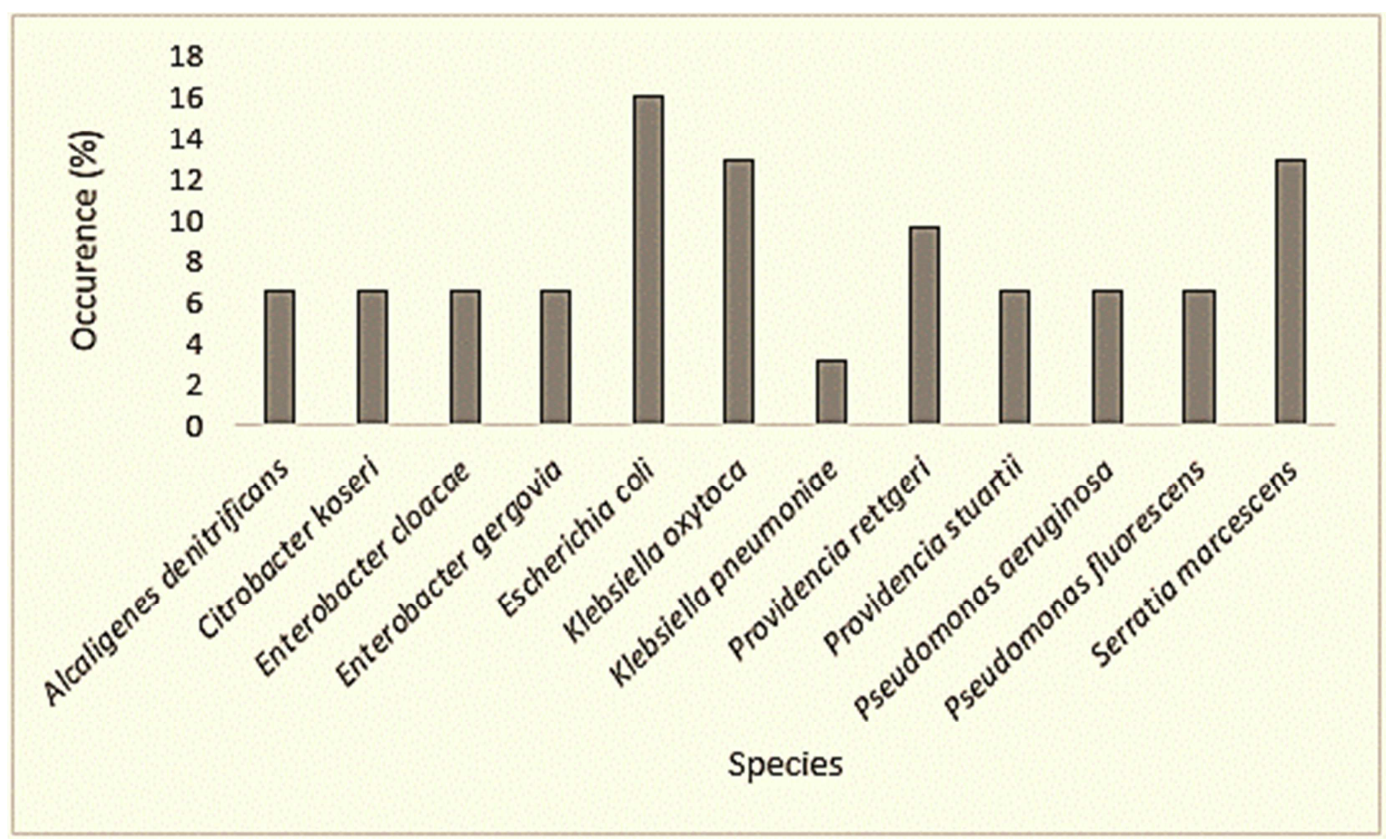

Figure 4. Frequency of occurrence of bacterial species harvested. 
Of the 21 samples we had a positivity of $84.6 \%$ representing 22 positive samples and on these we have 13 $(59.1 \%)$ samples where only one seed was identified and 9 $(40.9 \%)$ sample where two germs were identified (Table 1).

Table 1. Frequency of samples according to their positivity.

\begin{tabular}{lll}
\hline & Effectif (n) & Pourcentage \\
\hline Identified Bacteria $(\mathrm{n}=21)$ & & \\
Yes & 17 & 84,6 \\
No & 4 & 15,4 \\
Number of germs identified $(\mathrm{n}=17)$ & & \\
1 germ & 10 & 59,1 \\
2 germs & 7 & 40,9 \\
\hline
\end{tabular}

Table 2. Presence of germs according to the site of sampling.

\begin{tabular}{llll}
\hline & \multicolumn{2}{l}{ Bactéries } & \multirow{2}{*}{ Total } \\
\cline { 2 - 3 } & Non (\%) & Oui & \\
\hline Wells & & & $14(53,8 \%)$ \\
Yes & $1(3,8 \%)$ & $13(50 \%)$ & $12(46,2 \%)$ \\
No & $3(11,5 \%)$ & $9(34,6 \%)$ & \\
Springs & & & $7(26,9 \%)$ \\
Yes & $3(11,5 \%)$ & $4(15,4 \%)$ & $19(73,1 \%)$ \\
No & $1(3,8 \%)$ & $18(69,2 \%)$ & \\
Streams & & & $5(19,2 \%)$ \\
Yes & $0(0 \%)$ & $5(19,2 \%)$ & $21(80,8 \%)$ \\
No & $4(15,4 \%)$ & $17(65,4 \%)$ & \\
\hline
\end{tabular}

Puits: Khi- $2=1,58$ et $\mathrm{p}=0,31$ source: Khi-2 $=5,55 ; \mathrm{p}=0,047$ cours d'eaux: Khi-2=1,13; $\mathrm{p}=0,55$.

According to the sampling site, it appears that in the well water (53.8\% of samples), the positivity was marked by $50 \%$ of all the samples, ie 13 samples positive while only $3.8 \%$ (1) of these samples was sterile. $34.6 \%$ represents all the samples that are not wells containing seeds. With regard to spring water, $15.4 \%$ of the samples showed sprouts, ie 4 samples, while the absence of sprouts was marked by $11.5 \%$ of the samples compared to the number of initial samples of waters not sources, $69.2 \%$ contain germs and $3.8 \%$ do not contain them. Of the stream samples, all were positive, $19.2 \%$ of all samples.

\subsection{Relationships Between Abiotic and Biotic Parameters}

The affinities between the collection points corresponding to the different sampling stations were searched using the Bray Curtis index (also called Hierarchical Classification Analysis (ACH)) with a dendrogram [5]. Ward's aggregation method allowed clustering between nodes. This dendogram shows us a group of stations in three nuclei. The core I having $90.84 \%$ affinities consists of the stations ((W1-W2) (W4-R2) - (R1-R4) - (S2-W7)) grouped in pairs for the measured parameters. Then, the nucleus II which regroups the stations ((W3-W8) - (W6-W11) - (W10-R3-W9-W12) related to $86.73 \%$ The nucleus II has a similarity Core II has a similarity of $76.4 \%$ with S3. Core III consists of ((S1-S5) S4) stations. S1 and S5 have 94\% affinities for the measured parameters and share $73 \%$ similarity with S4. Well W13 stands out from other stations and has only $20 \%$ affinity with other stations

\section{Dendrogramme}

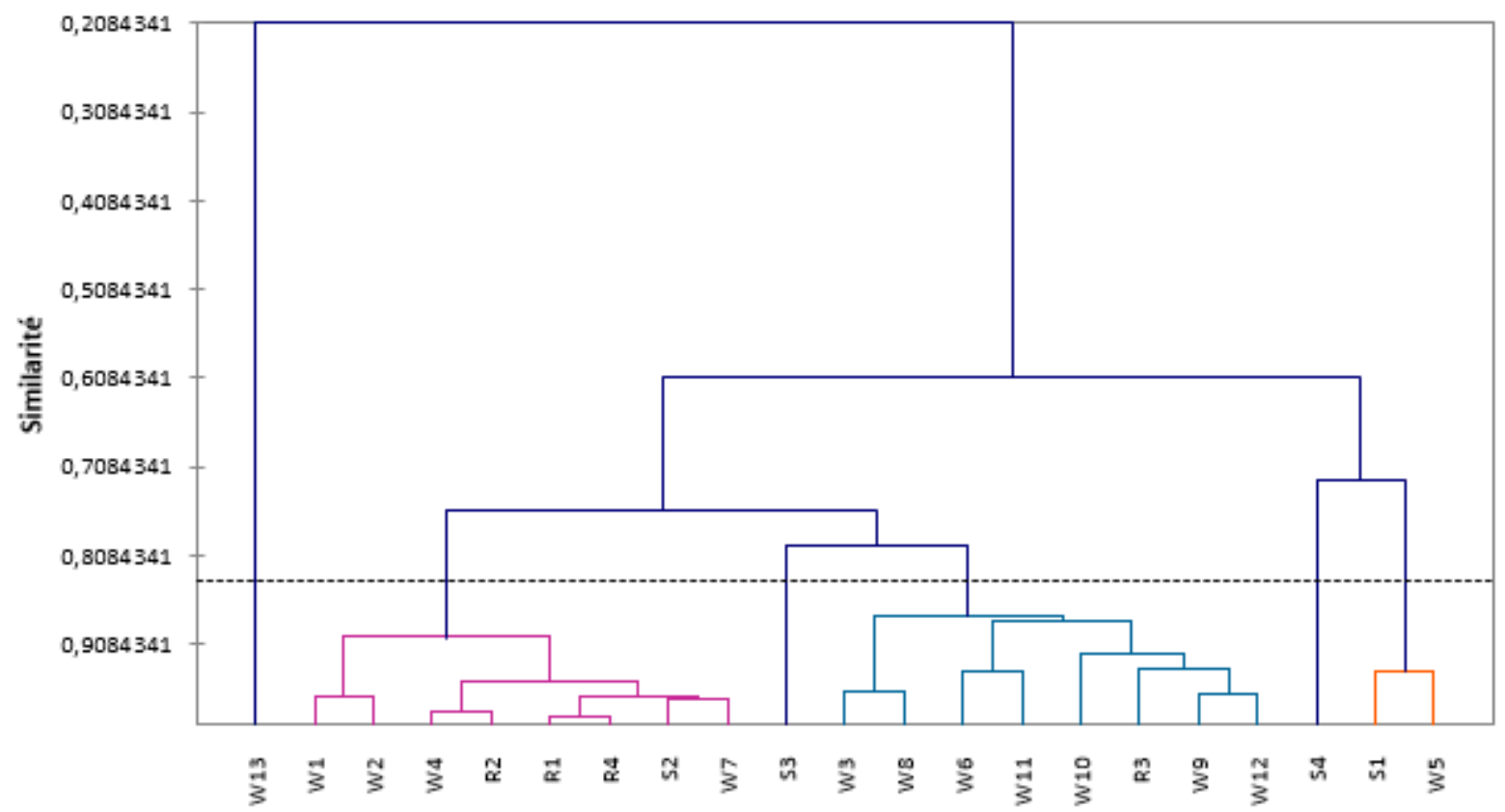

Figure 5. Dendrogram showing the affinities between the stations according to the physicochemical and biological parameters.

Dependence relationships between physicochemical and biological variables and different water bodies were investigated using a Principal Component Analysis (PCA) and the Canonical Correspondence Analysis (CAC). They make it possible to know the physical, chemical or biological variables that characterize each station. These analyzes 
cumulate $58.55 \%$ of the total variance. As a first step, biological variables are taken into account, we observe a grouping into two groups according to the contributions of bacterial species. Group I consisting of Enterobacter gergovia, Escherichia coli, Alcaligenes denitrificans Citrobacter koseri, Enterobacter cloacae species (Figure 6A) characterize the W7, W8 and S1 stations. Group II consists of

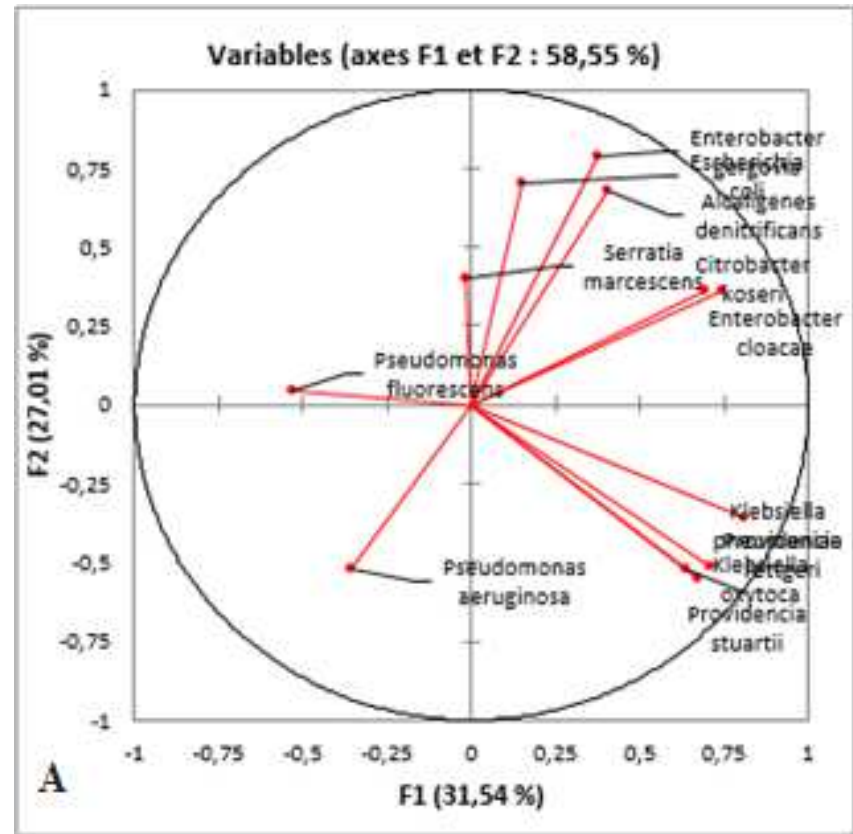

the species Klebsiella pneumoniae, Klebsiella oxytoca, Providencia stuartii and Providencia rettgeri which contribute mainly for the stations S2, W9, W10, W3 and R1. While the species that contribute to the characterization of water bodies W1, W2, W4, W5, W6, W11, W12, W13, R2, R4, S3 and S4 are Pseudomonas aeruginosa. Pseudomonas fluorescens and Serratia marcescens.

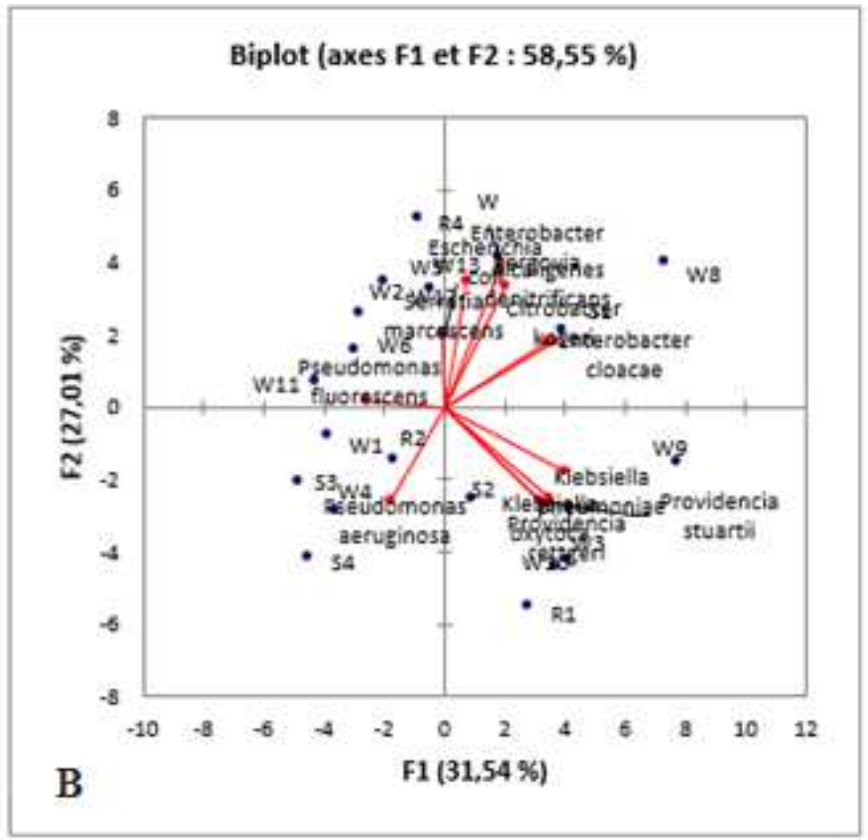

Figure 6. Representation of the dispersion of the biotic variables (A) in the study stations studied (B).

Biplot (axes F1 et F2 : 32,09 \%)

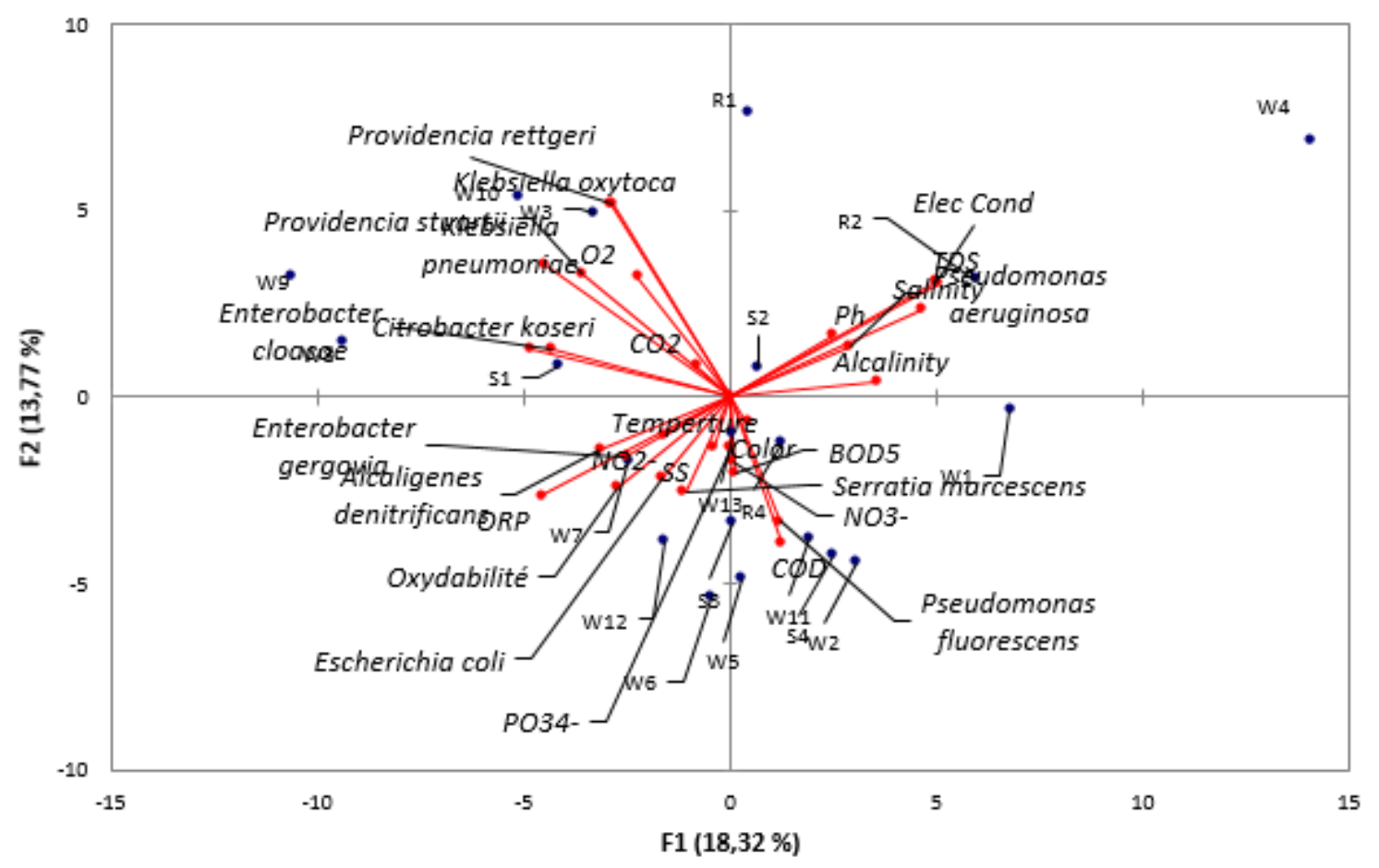

Figure 7. Representation of the dispersion of the stations according to the biotic and abiotic variables.

In association with this characterization of the stations the

abiotic parameters, one obtains figure 7 below where the two 
main factors express $32,09 \%$ of the total variance with a grouping in three characteristic nuclei. Core I consists of the W4 R1 R2 and S2 stations characterized by the species Pseudomonas aeruginosa and the variables alkalinity, electrical conductivity and salinity. The stations W2, W5, W6, W12, W11, S3 and S4 are characterized by the presence of the species Pseudomonas fluorescens, Alcaligenes denitrificans Escherichia coli and Serratia marcescens and abiotic variables such as nitrites, $\mathrm{BOD}_{5}$ and oxidability. $\mathrm{CO}_{2}$ and DO characterize W9, W8, W3, S1, and W1 Providencia stuartii, Klebsiella pneumoniae, Klebsiella oxytoca, Enterobacter cloacae, Citrobacter koseri and Providencia rettgeri Enterobacter gergoviae.

\section{Discussion}

\subsection{Physico-chemical Characteristics}

The results of this work reveal that groundwater from the city of Yaoundé, taken from wells and springs, has very low temperatures. In groundwater, thermal variations are very low, due to the low conductivity of the soil [6]. This would explain the thermal stability in this environment. SSMs have low values except in well W2 where the values are relatively high; this is due to the fact that this well is downstream of a rubbish dump and especially its bad maintenance (absence of coping and cover in bad condition). The protection of wells and springs, by setting up high rims, would prevent the risk of water pollution [7]. The dissolved oxygen levels recorded in the waters show that these waters are moderately oxygenated. In groundwater, dissolved oxygen levels are relatively low compared to surface water levels due to lack of photosynthetic plants, poor water-atmosphere contact, and lack of water turbulence. [8]. Nevertheless, a rapid circulation, resulting in a perpetual renewal of water, sometimes ensures a good oxygenation of the water, in hypogeous environment [9]. The relatively low values of the electrical conductivity indicate a weak mineralization of these waters, but still reflect according to a certain state of organic pollution. They estimate that waters less than 500 $\mu \mathrm{S} . \mathrm{cm}^{-1}$ are weakly mineralized [10]. In addition, the values of the redox potential are inversely proportional to the electrical conductivity, reflecting the low mineralization. The low POR values (Figure 2B) show that the waters are unfavorable to aquatic life and difficult to disinfect $[11,12]$. Indeed, the POR is a chemical complex due to its electrochy which involves unbalanced processes and difficult to predict or correct.

The values of oxidability reflect a richness of the water in organic matter, which according to some, [10] indicates a certain state of pollution. This conclusion corroborates suggestions made from electrical conductivity. It is likely that greywater and sewage seeping into the soil will reach the water table without being effectively filtered, causing occasional pollution. Such observations have been made [13] in Niger's groundwater. Groundwater naturally does not contain nitrogen compounds. These come from the decomposition of living matter by microorganisms. The excess of nitrogen from the artificial increase (agricultural fertilizers) is finally driven towards the aquifer [14]. These waters are rich in nitrites. Finally, physico-chemistry shows that the waters of the Yaounde wells are slightly basic, hard, weakly mineralized, poorly oxygenated and rich in organic matter; they cannot therefore be recommended as drinking water without prior treatment.

\subsection{Bacteriological Characteristics}

The results of the bacteriological analysis of the waters show that $50 \%$ of the wells, $19.2 \%$ of the rivers and $15.4 \%$ of the sources were polluted. During the analysis, we found germs indicating bacteriological pollution such as Escherichia coli with a frequency of (16.1\%). This species is indicative of recent faecal pollution, its high occurrence in the environment would result in permanent or constant contamination by wastewater or sewage. The presence of Alcaligenes denitrificans (6.5\%) and Pseudomonas correlated with nitrite content is related to the fact that these bacteria are flagellated and able to reduce nitrates [15]. Among these germs, those that are potentially pathogenic for humans and of faecal origin are: Klebsielle Pneumoniae (3.2\%), Klebsiella oxytoca (12.9\%), Enterobacter spp (Gergoviae and Cloacae) (6.5\%), Citrobacter koseri (6.5\%) and Escherichia coli $(16.1 \%)$.

These frequencies of bacteriological pollution indices are higher in well water than in source water and watercourses. This is probably because well water is stagnant, favoring the deposition of suspended particles. Several authors have found this same results; notably $[16,17]$ on the quality of tap water, springs and wells in the city of Dschang in Cameroon, [18] on the wells of Grand-Popo in Benin, [19] on well water and drinkable sources in the city of Santchou in Cameroon, as well as [20] on the bacteriological quality of water in Abomey-Calavi, Benin. The presence of these germs in a drinking water sample includes that of various other pathogens including viruses (Hepatitis A virus) and protozoa (Entamoeba hystolitica, Giardia sp and Cryptosporidium sp) $[21,22]$. The high rates of people with waterborne diseases indicate that treatments provided before consumption are not appropriate. In fact, the disinfection of the wells is done most often through the annual emptying by introduction of $1 / 4$ of bleach or a small amount of cooking salt (1 glass) per month. The use of bleach is very efficient for the treatment of water, if and only if the dosages are correctly observed [1,23].

\section{Conclusion}

At the end of this prospective study conducted in the city of Yaounde on the physicochemical quality of water and its influence on the dynamics of bacteria circulating in water points for domestic use in Yaoundé (Cameroon) carried out from March to September 2018, the waters are generally rich in organic matter, nitrogen and phosphates weakly mineralized, moderately conductive and subject to a medium organic pollution. The results of the bacteriological analysis 
of the waters show that $50 \%$ of the wells, $15.4 \%$ of the springs and $19.2 \%$ of the streams were contaminated. It shows that these waters are home to numerous bacterial communities including Pseudomonas aeruginosa and fecal contamination indicator germs such as Klebsiella oxytoca (12.9\%), Klebsiella pneumoniae (3.2\%), Citrobacter koseri (6.5\%) and Escherichia coli (16.1\%). These densities of bioindicators are not significantly correlated $(\mathrm{P}>0.05)$ with the abundance of Serratia marcescens in the wells, with Enterobacter cloacae and Escherichia coli in the watercourses, whereas they are significantly related. ( $P$ $<0.05)$ to the presence of Alcaligenes denitrificans, Enterobacter gergoviae, Escherichia coli and Providencia rettgeri in the sources. The presence of these germs in water for domestic use suggests health risks for user populations. To better understand the factors of virulence and resistance to disinfection, we plan to extend this study to the molecular analysis of the different bacterial strains harvested.

\section{References}

[1] Volk C., Joret J. C. 1994. Predictive parameters of the appearance of coliforms in food-water distribution networks; Journal of Water Sciences; 7: 131-152.

[2] Bied-Charreton M., Raoudha Makkaoui et al. 2006. Governance of Water Resources in Developing Countries: National and Global Issues; Developing world; 39-62.

[3] DHS (Demographic and Health Surveys). 2019. Demographic and Health Surveys Cameroon 2018: Key indicators; National Institute of Statistics; Ministry of Public Health Yaoundé, Cameroon. The DHS Program, ICF, Rockville, Maryland, USA.

[4] Rodier J., Merlet N., Lugube B. 2009. The analysis of water. 9th edition, Dunod, Paris, $1526 \mathrm{p}$.

[5] Nebout T., Desroy N., Mao P. 2010. Coordination of the study of benthic settlements in the Seine- Normandy district as part of the Rebent-DCE-Manche surveillance monitoring. I. 80 p.

[6] Ait Boughrous A. 2007. Biodiversity, ecology and groundwater quality of two arid regions of Morocco: Tafilalet and the Marrakech region. PhD thesis, Faculty of Sciences. Cadi Ayyad University Semlalia, Marrakech, Morocco. 236 p.

[7] Boutin C. 1993. Water from shallow groundwater, a vital but vulnerable natural resource. The example of rural areas of Morocco. Journal of Water Science, 6 (3): 357-365.

[8] Ginet R., Decou V. 1977. Initiation to biology and underground ecology. J. P Delarge edition, Paris France. 345p.

[9] Abdelbaki C., Bouklihacene F. 2007. Study of the groundwater degradation phenomenon of the Tlemcen urban group, Renewable Energies Review, 10 (2): 257-263.

[10] Nisbet M. and Vernaux J. 1970. Chemical components of running waters. Discussion and proposal of classes as bases of interpretation of chemical analyzes. Annals of Limnology; 6 (2): 161-190.

[11] Pankow R., James F. 1991. Aquatic Chemistry Concepts. Redox potential as an environmental parameter. Conceptual significance and operational limitation. Water Pollution Research Journal of Canada, 3 (1): 283-308.

[12] APHA 2005. American Public Health Association (APHA), American Water Works Association (AWWA), Water Environment Federation (WEF), Standard Methods for the Examination of Water and Wastewater; 21e edition, $1520 \mathrm{p}$.

[13] Chippaux J. P., Houssier Sgross P., Bouvier C., Brissaud F. 2002. Study of the pollution of groundwater of the city of Niamey, Niger. Bulletin of the Exotic Pathology Society, 94 (2): 119-123.

[14] WHO. 2011. Weekly Epidemiological Record, WHO Library Cataloging-in-Publication, 31: 325-340.

[15] Leifson, Hugh. 1954. Search for glucose pathway. Search for the respiratory type. Portal of Biology; CC -SA, 4 p.

[16] Neveu A., Riou C., Bonhomme R., Chassin P., Papy F. 2001. Water in rural areas. Life and Aquatic Environment, Paris: INRA, France, 105p.

[17] Allouche F., Lamri D., Zahf F. 1999. Monitoring of the bacteriological and physicochemical quality of the contaminated waters level of the three communes: Ali Boussid, Saby, Ben Badis, wilaya of Sidi Bel Abbes. Master's thesis in biology, University of sidi bel Abbes $72 \mathrm{p}+$ Appendices.

[18] Degbey C., Makoutode M. et al. 2011. Factors Associated with Well Water Quality and Prevalence of Waterborne Diseases in the Municipality of Abomey-Calavi (Benin) French-Language Study and Research Paper 21 (1): 47-55.

[19] Sharpe M. E. 1979. Identification of the lactic acid bacteria, identification methods for resisting bacteria in a drinking water treatment plant. Environmental microbiology; 10 (10): 2728-2745.

[20] Saunders AM, Kristiansen A. et al. 2009. A Detection And persistence of fecal Bacteroidales as water quality indicators in unchlorinated drinking water. Systems of Applied Microbiolology; 32: 362-370.

[21] Ajeagah G. A., Njiné T., Nola M., Foto Menbohan S., Wouafo N. M. 2007. Evaluation de l'abondance des formes de résistance de deux protozoaires pathogènes (Giardia sp. et Cryptosporidium sp.) dans deux biotopes aquatiques de Yaoundé (Cameroun). Cahier d'Etudes et de Recherche Francophones/Santé; 17 (3): 167-172.

[22] Ajeagah G. A., Njine T., Bilong Bilong C. F., Foto Menbohan S., Wouafo Ndayo M., Nola M., Di Giovanni G. D., Huw S. 2010. Seasonal Distribution of Enteric Opportunistic Cryptosporidium spp. Oocysts and Giardia spp. Cysts in a tropical Water Basin, Cameroun. WATER; 12 (1): 44-57.

[23] Makoutode, Assani A. K. et al. 1999. Quality and management of well water in rural Benin: the case of the Grand Popo sub prefecture. Medicine of Black Africa 46 (11): 528-534. 